\title{
Contribution of isoprene to formaldehyde and ozone formation based on its oxidation products measurement in Beijing, China
}

\author{
Xiaobing Pang ${ }^{\mathrm{a}, \mathrm{b}}$, Yujing Mu ${ }^{\mathrm{b}, *}$, Yujie Zhang ${ }^{\mathrm{b}}$, Xinqing Lee ${ }^{\mathrm{a}}$, Juan Yuan ${ }^{\mathrm{c}}$ \\ a State Key Laboratory of Environmental Geochemistry, Institute of Geochemistry, CAS, Guiyang 550002, China \\ ${ }^{\mathrm{b}}$ Research Center for Eco-Environmental Sciences, CAS, Beijing 100085, China \\ ${ }^{\mathrm{c}}$ Foreign Languages Faculty, Jiangxi University of Finance $\mathcal{E}$ ' Economics, Nanchang 330013, China
}

\section{A R T I C L E I N F O}

\section{Article history:}

Received 5 July 2008

Received in revised form

13 November 2008

Accepted 16 January 2009

\section{Keywords:}

Isoprene

Formaldehyde (HCHO)

Methacrolein (MACR)

Methyl vinyl ketone (MVK)

Ozone formation potential (OFP)

\begin{abstract}
A B S T R A C T
The atmospheric mixing ratios of methacrolein (MACR) and methyl vinyl ketone (MVK), the two specific products from isoprene oxidation in the atmosphere, were measured in Beijing from March to November, 2006. Distinct amounts of MACR and MVK were detected during vegetable growing seasons from April to October with ambient levels of 0.11-0.67 ppbv and 0.19-1.36 ppbv, respectively. The reacted isoprene and its ozone formation potentials (OFPs) in Beijing were evaluated in the range of 0.49-3.46 ppbv and 6.4$44.7 \mathrm{ppbv}$, respectively, from April to October. OFP of the reacted isoprene accounted for $10.6-23.6 \%$ of the total OFPs of VOCs (including carbonyls and isoprene) and $6.38-29.9 \%$ of the photo-chemically produced ozone. The maximum OFP of the original emitted isoprene prior to its photo-oxidation was calculated as $56.0 \mathrm{ppbv}$ in August. The contribution from the reacted isoprene in Beijing to $\mathrm{HCHO}$ formation was also estimated to be in the range of $0.35-2.45 \mathrm{ppbv}$ from April to October, which accounted for $4.6-11.5 \%$ of ambient HCHO.
\end{abstract}

(c) 2009 Elsevier Ltd. All rights reserved.

\section{Introduction}

Isoprene $\left(\mathrm{C}_{5} \mathrm{H}_{8}\right)$ is the principal non-methane volatile organic compound (VOC) emitted from vegetation. Its global emission was estimated to be $500-750 \mathrm{Tg} \mathrm{yr}^{-1}$ (Guenther et al., 2006), which is several times higher than the anthropogenic VOCs emissions $\left(100-200 \mathrm{Tg} \mathrm{yr}^{-1}\right)$ (Olivier and Berdowski, 2001), and typically more reactive than anthropogenic VOCs (Abelson, 1988). Researches conducted over the past decades have shown that isoprene contributes significantly to tropospheric ozone formation in rural (Trainer et al., 1987), suburban (Starn et al., 1998), and even urban areas (Chameides et al., 1988; Biesenthal and Shepson, 1997; Lee and Wang, 2006).

Recently, ozone formation potentials (OFPs) based on the observed atmospheric VOCs in a typical region were widely utilized to evaluate the reaction activity of the individual species to local atmospheric ozone formation (Wiedinmyer et al., 2001; Duane et al., 2002; Duan et al., 2008). However, the evaluation only based on the observed VOCs may result in underestimation, especially for

\footnotetext{
* Corresponding author. Research Center for Eco-Environmental Sciences, CAS, Atmospheric Chemistry, 18 Shuangqing Road, Haidian District, Beijing 100085, China. Tel.: +8610 62849125; fax: +8610 62849369.

E-mail addresses: pangxb1978@hotmail.com (X. Pang), yjmu@rcees.ac.cn (Y. Mu).
}

those species with high reactivity in the atmosphere (Song et al., 2007; Xie et al., 2008). Isoprene is just one of the most reactive VOCs, with atmospheric residual lifetime typically less than $1 \mathrm{~h}$ only respecting to the $\mathrm{HO}$ radical reaction during daytime (Trainer et al., 1987). Therefore, in addition to the observed ambient isoprene, isoprene consumed by photo-oxidation should be considered for OFPs evaluation. MVK and MACR are two specific products of isoprene photo-oxidation. The reacted isoprene can be quantified based on the observed MVK and MACR according to the approach developed by Atkinson (1997). Then, the more accurate OFP value for isoprene could be derived based on the observed isoprene plus the reacted isoprene.

During isoprene photo-oxidation process, formaldehyde ( $\mathrm{HCHO}$ ) can be produced in high yield (Finlayson-Pitts and Pitts, 1986). $\mathrm{HCHO}$ is considered as the major source for $\mathrm{HO}_{2}$ free radical in the troposphere and also makes important contribution to ozone formation. Furthermore, $\mathrm{HCHO}$ is a toxic and carcinogenic air pollutant with potential or direct negative effects on human health. Recently, the contribution of atmospheric isoprene to $\mathrm{HCHO}$ has attracted many researchers' interest (Wiedinmyer et al., 2001; Duane et al., 2002; Mu et al., 2007).

The vegetation coverage in Beijing has significantly increased during past decades and the proportion of greening area was high up to $42.5 \%$ of total urban area in 2006 (Beijing Bureau of Statistics, 2007). The main species for greening are various broad-leaf 
deciduous trees, shrubbery, and lawn, and most of them are strong isoprene emitters, e.g. the dominant deciduous trees, Platanus orientalis, Populus simonii, and Salix matsudana Koidz (Zhang et al., 2000). The increased greening area will definitely lead to the significant increase of isoprene emission. Although vegetables are beneficial to human's living environments in many aspects, its adverse impacts should also be considered especially for photooxidants formation which will have significantly adverse influence on human health and eco-environment. It is well documented that the biogenic isoprene emission is affected by various factors including solar radiation, air temperature, leave age etc. and shows distinct seasonal variation (Duane et al., 2002; Guenther et al., 2006). Therefore, long-term field measurements in Beijing are necessary to investigate the contribution of isoprene to atmospheric ozone and HCHO.

In recent two studies conducted in Beijing urban area, both the reacted isoprene and the observed isoprene were considered to estimate the OFPs of isoprene (Song et al., 2007; Xie et al., 2008). The calculated OFP of isoprene accounted for $12.3 \%$ and $23 \%$ of the total OFPs for all VOCs in summer of 2005 (Song et al., 2007) and summer of 2006 (Xie et al., 2008), respectively. However, those studies were just based on a short-term (only one month) field measurements and the contribution of isoprene to $\mathrm{HCHO}$ formation was not investigated.

In this study, the mixing ratios of MACR and MVK in Beijing urban air were measured from March to November in 2006, and the reacted isoprene was subsequently calculated. The ozone and formaldehyde formation potentials of atmospheric isoprene were estimated.

\section{Experimental}

\subsection{Site description}

Beijing city $(39.81 \mathrm{~N}, 116.51 \mathrm{E})$ is located in temperate zone with half-moist continent monsoon climate and four distinct seasons. Deciduous plants usually germinate at the end of March, flourish from April to September, and wither in the middle of October. In this study, field sampling was conducted from March to November 2006 on a rooftop (about $15 \mathrm{~m}$ above ground) in the Research Center for Eco-Environmental Sciences (RCEES), which is located between the north forth-ring road and the north fifth-ring road of Beijing and is a typical downtown site. The surroundings of RCEES are several institutes, campuses, residential apartments, and two side roads with moderate traffic. The RCEES is moderately covered by various plants, including P. orientalis, Pendula loud, P. simonii, and S. matsudana koidz, etc., which is a representative site of Beijing dwelling district.

\subsection{Carbonyls sampling and analysis}

The whole sampling campaign was conducted from March to November 2006. Air samples were usually collected from 08:00 a.m. to 20:00 p.m. (LT, Beijing time) in the days with sunny and stable weather condition. The sampling days for each month were 5 days for March, 7 days for April, 3 days for May, September and December, respectively; 4 days for June, July, and October, respectively; 6 days in August.

The carbonyls sampling and analysis were based on the EPA TO11A method (EPA, 1999). The detailed information about the atmospheric carbonyls sampling and analysis was described in our previous works (Pang and Mu, 2006; Mu et al., 2007). Ground-level ozone and $\mathrm{NO}_{2}$ were measured using an ozone analyzer (TE, Model 49) and a NO- $\mathrm{NO}_{2}$ analyzer (Monitor Labs ML9830 Series). Photosynthetically active radiation (PAR) was measured with a LI-COR quantum sensor (LICOR, Lincoln, NE, USA).

\section{Results and discussion}

Ten species of carbonyl compounds were identified in the ambient air of Beijing in this study including methyl vinyl ketone (MVK), mathacrolein (MACR), formaldehyde (Form), acetaldehyde (Acet), acetone, propionaldehyde (Propin), butyraldehyde (Butyr), hexaldehyde (Hex), valeraldehyde (Valer), and benzaldehyde (Benz). MVK, MACR and formaldehyde will be primarily discussed in the following sections.

\subsection{Diurnal variations of MVK, MACR and HCHO}

MVK and MACR were detected in 134 samples among 208 samples with their concentrations in the ranges of 0.12-2.36 and 0-1.25 ppbv, respectively. HCHO was found in all samples with its range of $1.6-52.0$ ppbv. Diurnal variations of MVK, MACR, and $\mathrm{HCHO}$ for each month were shown in Figs. 1 and 2, respectively. The peak concentrations of MVK and MACR in diurnal profiles usually appeared in the period from 10:00 a.m. to 16:00 p.m., which was in accordance with the period of daily peak emission of isoprene from deciduous trees in Beijing (Zhang et al., 2000), indicating that MVK and MACR in Beijing ambient air were predominantly produced from photo-oxidation of biogenic isoprene. Although MVK, MACR
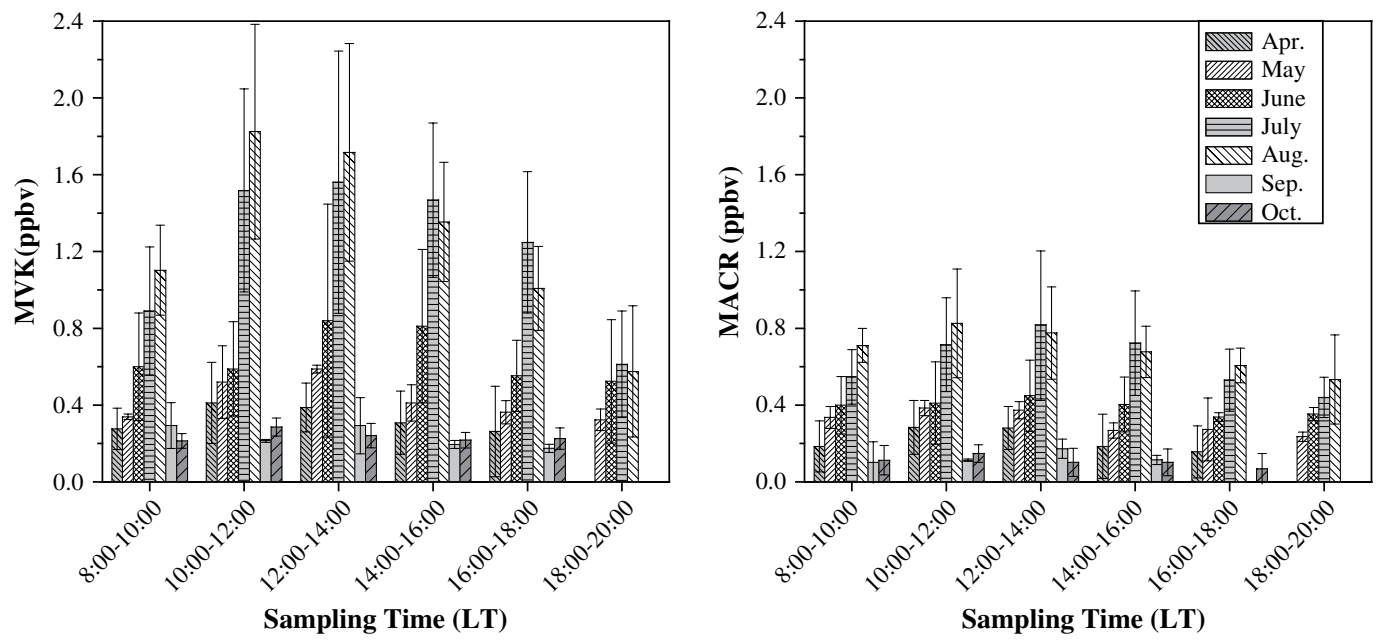

Fig. 1. Average diurnal variations of MVK (left plot) and MACR (right plot) during sampling months. 

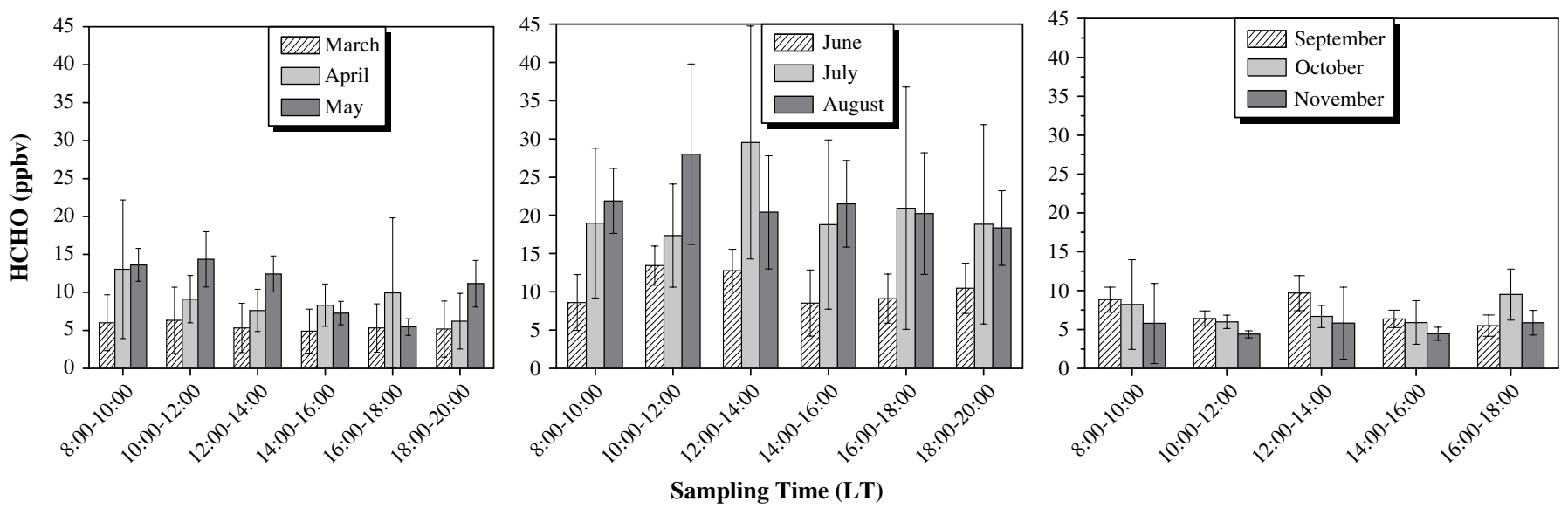

Fig. 2. Average diurnal variations of atmospheric $\mathrm{HCHO}$ concentrations during sampling months.

and isoprene had been even detected in vehicular emission (Biesenthal and Shepson, 1997), the atmospheric MVK and MACR were under the detection limits in March and November, and in most of evening time (during 18:00-20:00 h in April, September and October) in this study, implying that the anthropogenic contribution to MVK, MACR and isoprene might be negligible. In March and November, most deciduous trees around Beijing are in the periods of leaf emergence and leaf senescence, respectively, when biogenic sources were inactive and their isoprene emissions were quite weak (Steinbrecher et al., 1997; Zhang et al., 2000). So it is easy to understand why atmospheric MVK and MACR in Beijing were not detected until the later period of April, when the leaves of broad-leaf trees grow to their full expansions. The low concentrations of MVK and MACR in the evening may be also ascribed to the weak isoprene emission due to the low or no solar radiation (Lee and Wang, 2006). Fig. 3 is the diurnal profiles of MVK, MACR, air temperature, PAR, and ozone during the typical summer days (15-16 August, 2006). The similar trends among MVK, MACR, air temperature, PAR, and ozone further indicated MVK and MACR were mainly from biogenic isoprene photo-oxidation and elevated by the increasing air temperature and PAR.

During the whole sampling period, the concentration of MVK was significantly higher than that of MACR with the MVK/MACR ratios varying from 1.01 to 2.8 (Fig. 4). The MVK/MACR ratios were found to be usually maximum at noon and minimum in evening or morning. Similar phenomenon was also reported by Stroud et al. (2001) who observed the maximum ratio (2.0) in the early afternoon and minimum ratio (1.1) in night. In daytime, the photooxidation of isoprene was dominated by the reaction with $\mathrm{HO}$ radical as shown in equation (1) with the yield ratio for MVK/MACR of 1.5 (Atkinson, 1997). Additionally, as equation (2) and (3) shown, MACR can be lost faster than MVK in daytime by HO-initiated oxidation (Chuong and Stevens, 2004). So, a ratio exceeding 1.5 would be expected during daytime.

$$
\begin{aligned}
& \text { Isoprene }+\mathrm{HO} \rightarrow 0.32 \mathrm{MVK}+0.23 \mathrm{MACR}+\text { products } \\
& \mathrm{MACR}+\mathrm{HO} \rightarrow \text { products } k_{1}=3.22 \times 10^{-11} \\
& \quad\left(\mathrm{~cm}^{3} \text { molecule }{ }^{-1} \mathrm{~s}^{-1}\right)
\end{aligned}
$$

$$
\begin{aligned}
& \text { MVK }+\mathrm{HO} \rightarrow \text { products } k_{2}=1.78 \times 10^{-11} \\
& \left(\mathrm{~cm}^{3} \text { molecule }^{-1} \mathrm{~s}^{-1}\right)
\end{aligned}
$$

In the morning and evening, isoprene ozonolysis dominates over HO-initiated oxidation and the yields of MVK and MACR were
0.17 and 0.44 from isoprene ozonolysis (Warneke et al., 2004). Furthermore, MVK reacts faster with ozone than MACR (Yokouchi, 1994). In evening, the $\mathrm{NO}_{3}$ reaction can also cause rapid consumption of isoprene, while producing small amounts of MVK and MACR with their yields of 3.5\% (Kwok et al., 1996). So a low ratio would be expected from the ozonolysis reactions in the evening and morning.

HCHO was detected throughout the sampling period and found as the most abundant carbonyl compound in this study. As shown in Fig. 2, HCHO concentrations were low (about 6 ppbv) with little

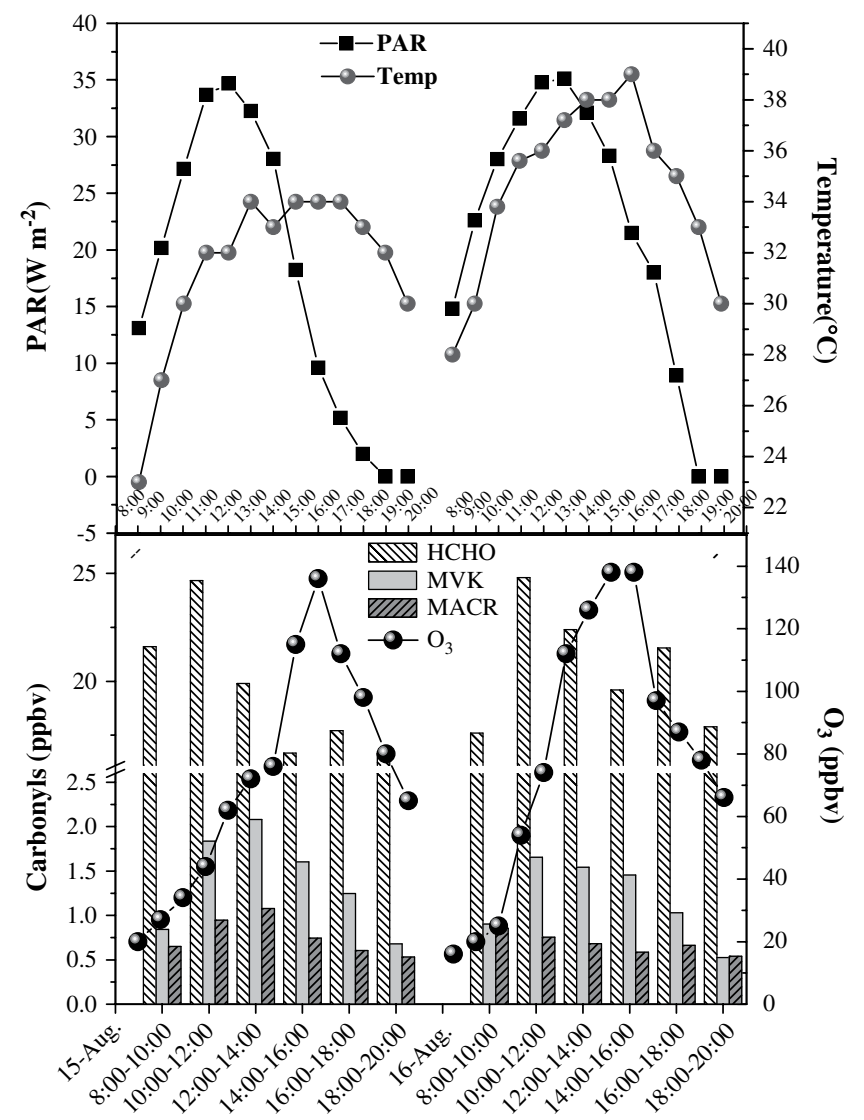

Fig. 3. Typical diurnal variations for MVK, MACR, HCHO, ozone, air temperature and PAR in typical summer days (15-16 August 2006). 


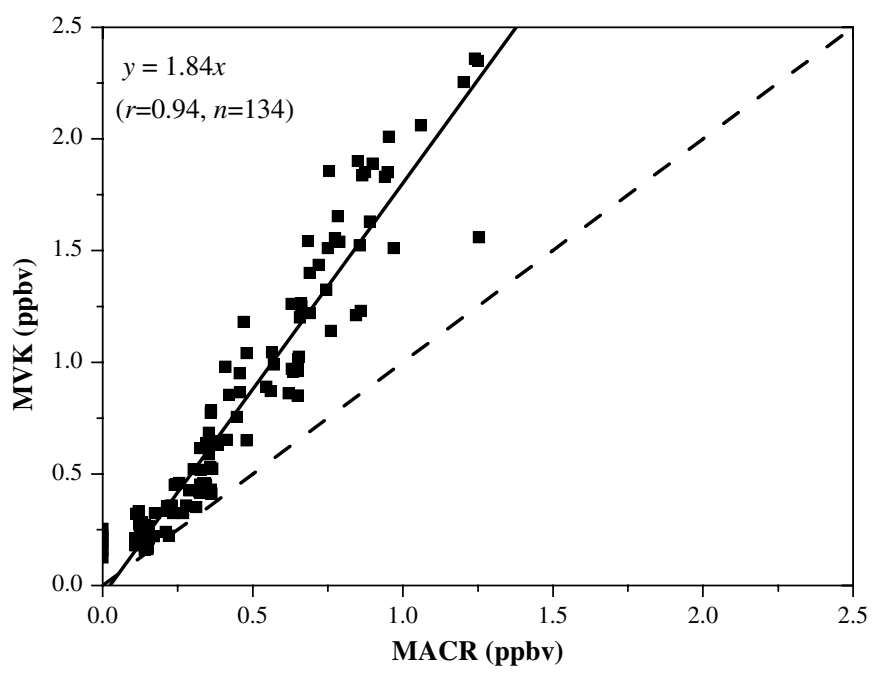

Fig. 4. Regression of MVK vs MACR during the whole sampling period.

variation in the diurnal patterns in March and December. In July and August, $\mathrm{HCHO}$ concentration was extremely elevated (up to 30 ppbv) and showed distinct diurnal variation due to significant contribution of photo-oxidation of VOCs to ambient HCHO (Pang and $\mathrm{Mu}, 2006$ ). Assuming that $\mathrm{HCHO}$ in March totally come from direct anthropogenic emission, and the strength of this direct emission was identical to those in other seasons, and the influence of meteorological conditions was neglected, the contributions from VOCs photo-oxidation to HCHO in Beijing could be roughly estimated from the data in Fig. 2 and account for $71 \%, 78 \%$ and $73 \%$ of total $\mathrm{HCHO}$ in June, July and August, respectively.

\subsection{Contribution of isoprene to HCHO and ozone formation potential}

In order to assess the relative importance of sources (biogenic versus anthropogenic) to atmospheric $\mathrm{HCHO}$, an attempt was done to estimate the concentration of $\mathrm{HCHO}$ attributed to isoprene photo-oxidation $\left([\mathrm{HCHO}]_{\text {isoprene }}\right)$. Assuming that the observed MACR and MVK in Beijing ambient air are absolutely derived from the isoprene oxidation by $\mathrm{HO}$ radical with their yields of 0.23 and 0.32 , respectively, the consumption of the reacted isoprene ( $\Delta$ isoprene) can be roughly estimated based on the measured MACR and MVK concentrations according to the following equation (4). This approach was commonly employed by numerous studies (Stroud et al., 2001; Duane et al., 2002; Mu et al., 2007).

$\Delta$ isoprene $=0.5[\mathrm{MACR}] / 0.23+0.5[\mathrm{MVK}] / 0.32$
Then, $[\mathrm{HCHO}]_{\text {isoprene }}$ can be calculated from the reacted isoprene according to the following equation (5)

$[\mathrm{HCHO}]_{\text {isoprene }}=f \Delta \mathrm{isoprene}(f=0.63)$

where $f$ is the total fractional yield of HCHO from isoprene oxidation (Carter and Atkinson, 1996). The amounts of HCHO derived from isoprene photo-oxidation for all samples were calculated and listed in Table 1. The maximum amount of HCHO from isoprene photo-oxidation was $6.0 \mathrm{ppbv}$ in the noon of 8 August 2006. As shown in Table 1 , the monthly average concentrations and the proportions of $\mathrm{HCHO}$ produced from isoprene oxidation varied over $0.35-2.53$ ppbv and $4.64-11.45 \%$, respectively, with peak values in August. These results indicated that the isoprene oxidation to atmospheric $\mathrm{HCHO}$ in Beijing cannot be neglected. It must be noted that the above approach is based on the crude assumption that the photochemical lifetime of MACR and MVK is much longer than that of isoprene (Carter and Atkinson, 1996; Atkinson, 1997). Although the reactions of MACR and MVK with HO are much slower than that of isoprene, the fast photolysis rates of MACR and MVK in summer midday should be considered, and the approach may underestimate the contribution of isoprene to $\mathrm{HCHO}$ under this condition.

To distinguish the contribution of individual VOC to ambient ozone is very important for efficiently control measure in the urban areas where ozone formation is VOC-sensitive. In most urban areas including Beijing, the ozone formation has been recognized to be controlled by VOCs due to plenty of $\mathrm{NO}_{x}$ in the ambient air (Xie et al., 2008; Song et al., 2007; Xu et al., 2006). The ozone formation potential (OFP), which is the product of the mixing ratio of VOC species and the maximum incremental reactivity (MIR) as developed by Carter (1994), is a widely used method for evaluating the maximum ozone formation capacity of each VOC and adopted in this study. As shown in Table 2, the OFPs of eight dominant carbonyls were calculated based on their monthly average concentrations and their MIR. Total OFPs of those carbonyls varied from 42.2 to $144.3 \mathrm{ppbv}$. Formaldehyde was found as the predominant contributor to the OFPs with values of 24.7$99.2 \mathrm{ppbv}$. The same finding in Beijing was also reported in the study of Duan et al. (2008).

The OFPs values derived by the observed VOC must be great underestimated for those (such as isoprene) with high reactivity in the atmosphere. Xie et al. (2008) found that the OFPs values for the total VOCs observed by them increased by $70 \%$ after considering the consumed VOCs via $\mathrm{OH}$ reaction during daytime. Lee and Wang (2006) also pointed out that the loss profile of a precursor is of greater interest to assess the impact on ozone formation, and they simulated the loss profile of isoprene under two scenarios based on the first order reaction of isoprene with $\mathrm{OH}$, and found the reacted

Table 1

Mixing ratios of $\mathrm{HCHO}$ (ppbv) derived from the reacted isoprene, isoprene contribution accounted for total ambient HCHO (\%) and the OFP of ambient HCHO.

\begin{tabular}{|c|c|c|c|c|c|c|c|c|c|}
\hline \multirow[t]{2}{*}{ Month } & \multirow{2}{*}{$\frac{08: 00-10: 00}{\text { Mean } \pm \text { SD }}$} & \multirow{2}{*}{$\frac{10: 00-12: 00}{\text { Mean } \pm S D}$} & \multirow{2}{*}{$\frac{12: 00-14: 00}{\text { Mean } \pm S D}$} & \multirow{2}{*}{$\frac{14: 00-16: 00}{\text { Mean } \pm \text { SD }}$} & \multirow{2}{*}{$\frac{16: 00-18: 00}{\text { Mean } \pm S D}$} & \multirow{2}{*}{$\frac{18: 00-20: 00}{\text { Mean } \pm S D}$} & \multirow[t]{2}{*}{ Monthly average } & \multirow[t]{2}{*}{ Ambient $\mathrm{HCHO}$} & \multirow{2}{*}{$\begin{array}{l}\text { Isoprene } \\
\text { contribution }\end{array}$} \\
\hline & & & & & & & & & \\
\hline Mar. & $\mathrm{ND}^{\mathrm{a}}$ & ND & ND & ND & ND & ND & ND & 5.51 & $0 \%$ \\
\hline April & $0.88 \pm 0.01$ & $0.80 \pm 0.49$ & $0.75 \pm 0.28$ & $0.72 \pm 0.20$ & $0.48 \pm 0.39$ & ND & $0.73 \pm 0.35$ & 10.55 & $6.89 \%$ \\
\hline May & $0.88 \pm 0.02$ & $1.21 \pm 0.32$ & $1.11 \pm 0.08$ & $0.75 \pm 0.13$ & $0.72 \pm 0.14$ & $0.59 \pm 0.12$ & $0.88 \pm 0.14$ & 10.78 & $8.14 \%$ \\
\hline June & $0.77 \pm 0.13$ & $1.18 \pm 0.40$ & $1.34 \pm 0.78$ & $1.36 \pm 0.64$ & $0.98 \pm 0.19$ & $0.93 \pm 0.21$ & $1.09 \pm 0.42$ & 9.815 & $11.17 \%$ \\
\hline July & $1.58 \pm 0.48$ & $2.39 \pm 0.82$ & $2.55 \pm 1.17$ & $1.92 \pm 0.74$ & $1.61 \pm 0.53$ & $1.27 \pm 0.36$ & $1.88 \pm 1.04$ & 19.90 & $9.48 \%$ \\
\hline Aug. & $1.21 \pm 0.24$ & $3.54 \pm 1.05$ & $2.79 \pm 0.84$ & $2.19 \pm 0.47$ & $1.78 \pm 0.31$ & $1.26 \pm 0.66$ & $2.53 \pm 0.74$ & 22.04 & $11.45 \%$ \\
\hline Sep. & $0.59 \pm 0.28$ & $0.40 \pm 0.09$ & $0.50 \pm 0.22$ & $0.23 \pm 0.19$ & $0.17 \pm 0.17$ & ND & $0.38 \pm 0.12$ & 5.49 & $6.88 \%$ \\
\hline Oct. & $0.29 \pm 0.12$ & $0.44 \pm 0.04$ & $0.34 \pm 0.11$ & $0.33 \pm 0.13$ & $0.33 \pm 0.13$ & ND & $0.35 \pm 0.15$ & 7.49 & $4.64 \%$ \\
\hline Nov. & ND & ND & ND & ND & ND & ND & ND & 4.46 & $0 \%$ \\
\hline
\end{tabular}

a Not detected. 
Table 2

OFP (ppbv) of ambient each carbonyl compound during the sampling period.

\begin{tabular}{lcclclllll}
\hline Carbonyls & Form & Acet & Acetone & Propion & Butyr & Hex & Valer & Benz & Total \\
\hline Mar. & 24.8 & 6.2 & 0.89 & 6.9 & 1.65 & 1.01 & 1.18 & -0.42 & 42.21 \\
April & 47.5 & 7.5 & 2.0 & 7.6 & 2.14 & 1.19 & 1.38 & -0.44 & 68.86 \\
May & 48.5 & 12.3 & 2.87 & 8.4 & 2.78 & 1.82 & 2.12 & -0.54 & 78.26 \\
June & 44.3 & 17.7 & 2.61 & 10.6 & 3.57 & 2.03 & 2.37 & -0.57 & 82.61 \\
July & 89.4 & 20 & 5.49 & 11.8 & 4.1 & 2.23 & 2.6 & -0.87 & 134.7 \\
Aug. & 99.2 & 21.3 & 1.88 & 13.0 & 4.33 & 2.41 & 2.81 & -0.63 & 144.3 \\
Sep. & 24.7 & 11.5 & 2.14 & 11.1 & 3.0 & 1.77 & 2.06 & -0.5 & 55.77 \\
Oct. & 33.7 & 8.9 & 1.46 & 9.7 & 2.09 & 0.97 & 1.13 & -0.41 & 57.54 \\
Nov. & 20.1 & 8.4 & 1.36 & 7.8 & 1.55 & 0.76 & 0.89 & -0.38 & 40.48 \\
\hline
\end{tabular}

isoprene is about 2.6-fold of the observed isoprene for the noontime peak value. Xie et al. (2008) calculated the initial isoprene mixing ratio based on the observed atmospheric isoprene, MVK and MACR and the first order reactions of isoprene, MVK and MACR with $\mathrm{OH}$. Both methods of Lee and Wang (2006) and Xie et al. (2008) provided important evidence that the consumed isoprene makes great contribution to ozone formation. However, the consumed isoprene calculated by the two methods can only represent the approximate value, because the reactions of isoprene, MVK and MACR with $\mathrm{OH}$ are not strictly according to the first order law in the actual atmospheric environment due to significant variations of isoprene emission and $\mathrm{OH}$ concentration. In addition, the value of $\mathrm{OH}_{\mathrm{avg}} t$ derived from the observed ratios of MVK to isoprene or MACR to isoprene by Xie et al. (2008) must be largely underestimated due to continuously isoprene emission from vegetables, and hence underestimated the consumed isoprene. In this study, the reacted isoprene was simply calculated according to the equation (4) based on the measured MACR and MVK. It should be mentioned that the reacted isoprene calculated by this study only represents the lower limit because the loss of MACR and MVK in the atmosphere were not considered. In Table 3, the monthly average concentrations of the reacted isoprene were estimated to be in range of $0.49-3.46 \mathrm{ppbv}$. The OFPs of the reacted isoprene were calculated in the range of 6.4-44.7 ppbv with maximum in August, which accounted for 10.6-23.5\% of the total OFPs of the measured VOCs including carbonyls and isoprene, and 6.4-29.9\% photo-chemically produced ozone (the observed ambient $\mathrm{O}_{3}$ and $\mathrm{NO}_{2}$ ).

Xie et al. (2008) reported the average mixing ratio of the atmospheric isoprene at Peking university site was $0.89 \pm 0.55 \mathrm{ppbv}$ during August and September 2006. Assuming that the average mixing ratio of atmospheric isoprene in August was identical to the average level ( $0.89 \mathrm{ppbv})$ at our sampling site, the total concentration of isoprene including the reacted isoprene and the atmospheric isoprene in August can be obtained as $4.34 \mathrm{ppbv}$ and its OFP can be estimated as $56.0 \mathrm{ppbv}$ which was about $40 \%$ higher than the value of OFP ( $42 \mathrm{ppbv}$ ) estimated by Xie et al. (2008). As mentioned above, the OFP value estimated by Xie et al. (2008) may be largely underestimated due to continually
Table 4

Comparison of $\mathrm{HCHO}, \mathrm{MVK}, \mathrm{MACR}$ and isoprene in various cities during summer time (ppbv).

\begin{tabular}{|c|c|c|c|c|c|c|}
\hline Cities & Sampling Time & $\mathrm{HCHO}$ & MVK & MACR & Isoprene & Refer. \\
\hline Beijing, (urban) & Aug-Sep., 2006 & $-{ }^{a}$ & 0.34 & 0.70 & 0.89 & $\begin{array}{l}\text { Xie et al., } \\
2008\end{array}$ \\
\hline Beijing, (rural) & & - & 0.37 & 0.55 & 0.64 & $\begin{array}{l}\text { Xie et al., } \\
2008\end{array}$ \\
\hline Beijing & Aug., 2006 & 26.82 & - & - & 1.17 & $\begin{array}{l}\text { Duan et al., } \\
2008\end{array}$ \\
\hline $\begin{array}{l}\text { Zürich } \\
\qquad \text { (Switzerland) }\end{array}$ & Summer & 2.35 & 0.08 & 0.04 & 0.16 & $\begin{array}{l}\text { Legreid } \\
\text { et al., } 2007\end{array}$ \\
\hline Insubria, Italy & Aug., 2000 & 4.0 & $\sim 5.0$ & $\sim 2.8$ & 20 & $\begin{array}{l}\text { Duane et al., } \\
2002\end{array}$ \\
\hline Nashville, USA & June-July, 1999 & - & 0.43 & 0.24 & 0.41 & $\begin{array}{l}\text { Stroud } \\
\text { et al., } 2001\end{array}$ \\
\hline $\begin{array}{l}\text { Austin, USA } \\
\text { (urban) }\end{array}$ & Aug, 1998 & $0.4-3.2$ & - & $0.2-5.7$ & $0.3-6.0$ & $\begin{array}{l}\text { Wiedinmyer } \\
\text { et al., } 2001\end{array}$ \\
\hline $\begin{array}{l}\text { Austin, USA } \\
\text { (rural) }\end{array}$ & & $0.4-20$ & - & $0.1-3.7$ & $0.3-10.2$ & \\
\hline $\begin{array}{c}\text { Vancouver, } \\
\text { Canada }\end{array}$ & Aug., 1993 & - & 2.0 & 1.0 & 5.3 & $\begin{array}{l}\text { Biesentha } \\
\text { et al., } 1997\end{array}$ \\
\hline $\begin{array}{l}\text { Kinterbish, } \\
\text { USA }\end{array}$ & June-July, 1990 & - & 0.98 & 0.66 & - & $\begin{array}{l}\text { Montzka } \\
\text { et al., } 1993\end{array}$ \\
\hline Beijing & Aug., 2006 & 22.04 & 1.36 & 0.67 & - & This study \\
\hline
\end{tabular}

${ }^{a}$ No reported data.

isoprene emission from vegetables. In addition, the temporal and spatial difference between the two measurements may also account for the discrepancy. Finally, the average mixing ratios of $\operatorname{MACR}(0.7 \pm 0.42 \mathrm{ppb})$ and MVK $(0.34 \pm 0.17 \mathrm{ppb})$ obtained by Xie et al. (2008) are contrary to the stoichiometric reaction of $\mathrm{OH}$ with isoprene as well as the different reactivity of MACR and MVK.

\subsection{Comparison of HCHO, MVK, MACR and isoprene in other cities}

As Table 4 shows, the atmospheric $\mathrm{HCHO}$ in Beijing city in August measured by this study is in good agreement with that of Duane et al. (2002), and significantly higher than those of other cities, indicating that the great amount of vehicular exhaust from millions of vehicles in Beijing city may be responsible. The MVK and MACR of Beijing are comparable with those of Nashville (Stroud et al., 2001) and Kinterbish (Montzka et al., 1993) but lower than those of cities surrounded by forest such as Insubria (Duane et al., 2002), Vancouver (Biesenthal et al., 1997) and Austin (Wiedinmyer et al., 2001). The atmospheric isoprene of Beijing is a few higher than those of a forest site in Nashville and an urban background site in Zürich (Legreid et al., 2007), which implies that the isoprene from biogenic source in Beijing is significant. The highest concentration of MVK, MACR and isoprene were reported in the Insubria of Italy, in which the isoprene's contribution to the local ozone formation was calculated to be as high as $50-75 \%$ in summer (Duane et al., 2002).

Table 3

Estimated OFP (ppbv) and maximum contributions of reacted isoprene to total OFP (\%) and photo-chemically produced ozone on monthly average value

\begin{tabular}{|c|c|c|c|c|c|c|c|c|}
\hline Month & $\begin{array}{l}\text { Observed } \\
\text { MACR }\end{array}$ & $\begin{array}{l}\text { Observed } \\
\text { MVK }\end{array}$ & $\begin{array}{l}\text { Reacted } \\
\text { isoprene }\end{array}$ & $\begin{array}{l}\text { OFP of reacted } \\
\text { isoprene }\end{array}$ & $\begin{array}{l}\text { OFP of } \\
\text { VOCs }^{\mathrm{a}}\end{array}$ & $\begin{array}{l}\text { Contribution } \\
\text { to OFP }\end{array}$ & $\begin{array}{l}\text { Photo-chemically } \\
\text { produced } \mathrm{O}_{3}\end{array}$ & $\begin{array}{l}\text { Contribution to photo-chemically } \\
\text { produced } \mathrm{O}_{3}\end{array}$ \\
\hline April & 0.18 & 0.27 & 0.79 & 10.2 & 79.06 & $12.9 \%$ & 68 & $15.0 \%$ \\
\hline May & 0.27 & 0.40 & 1.18 & 15.3 & 93.55 & $16.4 \%$ & 99.3 & $15.4 \%$ \\
\hline June & 0.33 & 0.52 & 1.49 & 19.2 & 101.8 & $18.9 \%$ & 91.0 & $21.1 \%$ \\
\hline July & 0.54 & 1.03 & 2.69 & 34.8 & 169.5 & $20.5 \%$ & 144.7 & $24.1 \%$ \\
\hline Aug. & 0.67 & 1.36 & 3.46 & 44.7 & 188.9 & $23.6 \%$ & 149.1 & $29.9 \%$ \\
\hline Sep. & 0.12 & 0.19 & 0.49 & 7.0 & 62.77 & $11.1 \%$ & 109.7 & $6.38 \%$ \\
\hline Oct. & 0.11 & 0.20 & 0.52 & 6.8 & 64.34 & $10.6 \%$ & 53.0 & $12.8 \%$ \\
\hline
\end{tabular}

a VOCs includes carbonyls and isoprene. 


\section{Conclusion}

In this study, the contributions of biogenic isoprene to ozone and $\mathrm{HCHO}$ in Beijing ambient air were estimated. The maximum ozone formation capacity for atmospheric isoprene in August was calculated to be $56.0 \mathrm{ppbv}$ and accounted for $37.5 \%$ of the photochemically produced ozone. The amounts of $\mathrm{HCHO}$ attributed to the reacted isoprene varied in the range of $0.35-2.53 \mathrm{ppbv}$ from April to October, which accounted for the $4.64-11.45 \%$ of total ambient $\mathrm{HCHO}$. It is evident that the contribution of biogenic isoprene in Beijing to local photo-oxidant formation is significant, especially during summer time. The estimations in this study provided useful information to the policy-maker of Beijing municipal government that the influence of biogenic isoprene should be considered in order to develop an effective control strategy for ground-level ozone abatement.

\section{Acknowledgements}

This research has received the financial support of the Chinese National Natural Science Foundation (20677067, 40830101, 20807041), the National Basic Research Program of China (2005CB422201), Chinese Academy of Sciences (KZCX2-yw-Q0203), China Postdoctoral Science Foundation (20080430861) and Municipal Science and Technology Foundation of Guizhou Province (2008GZ02725). Authors would like to thank two anonymous referees for their valuable comments.

\section{References}

Abelson, P.H., 1988. Rural and urban ozone. Science 241, 1569

Atkinson, R., 1997. Gas-phase tropospheric chemistry of volatile organic compounds: 1. Alkanes and alkenes. Journal of Physical and Chemical Reference Data 26, 215-290.

Beijing Bureau of Statistics, 2007. Beijng Statistics Yearbook 2007. China Statistics Press, Beijing (in Chinese).

Biesenthal, T.A., Shepson, P.B., 1997. Observations of anthropogenic inputs of the isoprene oxidation products methyl vinyl ketone and methacrolein to the atmosphere. Geophysical Research Letters 24, 1375-1378.

Carter, W.P.L., 1994. Development of ozone reactivity scales for volatile organic compounds. Journal of Air Waste Management Association 44, 881-889.

Carter, W.P.L., Atkinson, R., 1996. Development and evaluation of a detailed mechanism for the atmospheric reactions of isoprene and $\mathrm{NO}_{x}$. International Journal of Chemical Kinetics 28, 497-530.

Chameides, W.L., Lindsay, R.W., Richardson, J., Kiang, C.S., 1988. The role of biogenic hydrocarbons in urban photochemical smog - Atlanta as a case-study. Science 241, 1473-1475.

Chuong, B., Stevens, P., 2004. Measurements of the kinetics of the $\mathrm{OH}$-initiated oxidation of methyl vinyl ketone and methacrolein. International Journal of Chemical Kinetics 36, 12-25.

Duan, J., Tan, J., Yang, L., Wu, S., Hao, J., 2008. Concentration, sources and ozone formation potential of volatile organic compounds (VOCs) during ozone episode in Beijing. Atmospheric Research 88, 25-35.

Duane, M., Poma, B., Rembges, D., Astorga, C., Larsen, B.R., 2002. Isoprene and its degradation products as strong ozone precursors in Insubria, Northern Italy. Atmospheric Environment 36, 3867-3879.
EPA, 1999. Compendium of Methods for the Determination of Toxic Organic Compounds in Ambient Air. EPA Rep. EPA/625/R-96/010b. U.S. Environmental Protection Agency, Cincinnati, Ohio.

Finlayson-Pitts, B.J., Pitts, J.N., 1986. Atmospheric Chemistry Fundamentals and Experimental Techniques. Wiley, New York.

Guenther, A., Karl, T., Harley, P., Wiedinmyer, C., Palmer, P.I., Geron, C., 2006 Estimates of global terrestrial isoprene emissions using MEGAN (Model of Emissions of Gases and Aerosols from Nature). Atmospheric Chemistry and Physics 6, 3181-3210.

Kwok, E.S.C., Aschmann, S.M., Arey, J., Atkinson, R., 1996. Product formation from the reaction of the $\mathrm{NO}_{3}$ radical with isoprene and rate constants for the reactions of methacrolein and methyl vinyl ketone with the $\mathrm{NO}_{3}$ radical. International Journal of Chemical Kinetics 28, 925-934.

Lee, B.S., Wang, J.L., 2006. Concentration variation of isoprene and its implications for peak ozone concentration. Atmospheric Environment 40, 5486-5495.

Legreid, G., Lööv, B.J., Staehelin, J., Hueglin, C., Hill, M., Buchmann, B., Prevot, A.S.H., Reimann, S., 2007. Oxygenated volatile organic compounds (OVOCs) at an urban background site in Zürich (Europe): seasonal variation and source allocation. Atmospheric Environment 41, 8409-8423.

Montzka, S.A., Trainer, M., Goldan, P.D., Kuster, W.C., Fehsenfeld, F.C., 1993. Isoprene and its oxidation products, methyl vinyl ketone and methacrolein, in the rural troposphere. Journal of Geophysical Research 98, 1101-1111.

Mu, Y., Pang, X.B., Quan, J.N., Zhang, X.S., 2007. Atmospheric carbonyl compounds in Chinese background area: a remote mountain of the Qinghai-Tibetan Plateau. Journal of Geophysical Research-Atmospheres 112, D22302. doi:10.1029/ 2006JD008211.

Olivier, J.G.J., Berdowski, J.J.M., 2001. Global emissions sources and sinks. In: Berdowski, J., Guicherit, R., Heij, B.J. (Eds.), The Climate System. A.A. Balkema/ Swets and Zeitlinger, Lisse, The Netherlands, pp. 33-78.

Pang, X., Mu, Y., 2006. Seasonal and diurnal variations of carbonyl compounds in Beijing ambient air. Atmospheric Environment 40, 6313-6320.

Song, Y., Shao, M., Liu, Y., Lu, S., Kuster, W., Goldan, P., Xie, S., 2007. Source apportionment of ambient volatile organic compounds in beijing. Environmental Science and Technology 41, 4348-4353.

Starn, T.K., Shepson, P.B., Bertman, S.B., White, J.S., Splawn, B.G., Riemer, D.D., Zika, R.G., Olszyna, K., 1998. Observations of isoprene chemistry and its role in ozone production at a semirural site during the 1995 Southern Oxidants Study. Journal of Geophysical Research - Atmospheres 103, 22425-22435.

Steinbrecher, R., Hauff, K., Rabong, R., Steinbrecher, J., 1997. Isoprenoid emission of oak species typical for the Mediterranean area: source strength and controlling variables. Atmospheric Environment 31, 79-88.

Stroud, C.A., Roberts, J.M., Goldan, P.D., et al., 2001. Isoprene and its oxidation products, methacrolein and methylvinyl ketone, at an urban forested site during the 1999 Southern Oxidants Study. Journal of Geophysical Research Atmospheres 106, 8035-8046.

Trainer, M., Williams, E.J., Parrish, D.D., Buhr, M.P., Allwine, E.J., Westberg, H.H., Fehsenfeld, F.C., Liu, S.C., 1987. Models and observations of the impact of natural hydrocarbons on rural ozone. Nature 329, 705-707.

Warneke, C., de Gouw, J.A., Goldan, P.D., et al., 2004. Comparison of daytime and nighttime oxidation of biogenic and anthropogenic VOCs along the New England coast in summer during New England Air Quality Study 2002. Journal of Geophysical Research-Atmospheres 109.

Wiedinmyer, C., Friedfeld, S., Baugh, W., Greenberg, J., Guenther, A., Fraser, M., Allen, D., 2001. Measurement and analysis of atmospheric concentrations of isoprene and its reaction products in central Texas. Atmospheric Environment $35,1001-1013$

Xie, X., Shao, M., Liu, Y., Lu, S., Chang, C., Chen, Z., 2008. Estimate of initial isoprene contribution to ozone formation potential in Beijing, China. Atmospheric Environment 42, 6000-6010.

Xu, J., Zhang, Y., Wang, W., 2006. Numerical study on the impacts of heterogeneous reactions on ozone formation in the Beijing urban area. Advance in Atmospheric Sciences 23, 605-614.

Yokouchi, Y., 1994. Seasonal and diurnal-variation of isoprene and its reactionproducts in a semirural area. Atmospheric Environment 28, 2651-2658.

Zhang, X., Mu, Y., Song, W., Zhuang, Y., 2000. Seasonal variations of isoprene emissions from deciduous trees. Atmospheric Environment 34, 3027-3032. 